\title{
SERVICE MODULARISATION COMPATIBILITY TO ORGANISATIONAL OBJECTIVES
}

\author{
Ilona SKAČKAUSKIENĖ®, Jurga VESTERTE் (1)* \\ Department of Management, Faculty of Business Management, Vilnius Gediminas Technical University, \\ Saulètekio al. 11, 10223, Vilnius, Lithuania
}

Received 15 February 2021; accepted 1 April 2021

\begin{abstract}
Purpose - the article aims to explore how service modularisation objectives are compatible with organisational objectives.

Research methodology - the paper is a part of continuous research. It takes a conceptual approach and integrates relevant literature to develop a framework on the potential avenues to create a decision-support tool that assists in service modularity planning. The research proceeds with evidence from the peer-reviewed literature. The relevant literature was identified through "pearl growing" and citation chasing techniques using the assembled body of topic literature from authors' previous research and employing the related keywords for filtering.

Findings - the previous literature is silent on establishing objectives for service modularisation with the consideration of what a provider will achieve by engaging in this. The paper addresses this gap and discovers how antecedents of service modularisation transform into organisational objectives.

Research limitations - although bibliographic research methods are limited, they enable the analysis and identification of structure within the research. Such analysis has implications by suggesting future directions in investigating how modularity approach can be used in the service context and how it can be applied in practice more actively.

Practical implications - the findings provide potentially vital information to service organisation managers and allow better understand how service modularisation would benefit performance results in gaining service competitiveness.

Originality/Value - the study contributes to the discourse on service modularity planning and provides a basis for comprehension of service modularisation merit when pursuing competitiveness.
\end{abstract}

Keywords: service modularity, service modularization, planning, organisational objectives, balanced scorecard, service competitiveness.

JEL Classification: L21, L80, M11.

Conference topic: Contemporary Organizations Development Management.

\section{Introduction}

The service organisations are under pressure to seek solutions on how to achieve service excellence in a way that increases customer satisfaction cost-effectively. Service management literature proposes several strategic approaches for dealing with this challenge. One of them contains the service modularisation approach, allowing service organisations to attain a kind of equilibrium between service standardisation and customisation.

The modular strategy aligns with leveraging modular designed services' benefits to gain a competitive advantage in the market. According to Porter (1996), there are three main ways to gain a competitive advantage: to pursue cost leadership over competitors, to differentiate products by better suiting them to needs and wishes of customers, and to implement innovations. The modular design allows producing customisable service variants, not increasing the costs, thus enabling the opportunity to gain cost leadership and product differentiation at once.

Application of modular design principles allows creating a modular structure of a product system. It embodies a hierarchy between system blocks or modules that are relatively independent and have a functional purpose within the system but are loosely coupled to act in a coordinated manner as a whole (Baldwin \& Clark, 2000). The connections

*E-mail: jurga.vesterte@vilniustech.lt

(C) 2021 Authors. Published by Vilnius Gediminas Technical University. This is an open-access article distributed under the terms of the Creative Commons Attribution (http://creativecommons.org/licenses/by/4.0/) License, which permits unrestricted use, distribution, and reproduction in any medium, provided the original author and source are credited. 
between the elements inside the module are tight. If required, modules can be easily separated and combined anew, creating the desired product variant without increasing costs. Modular design for services manifests at various levels (Bask et al., 2011; Løkkegaard et al., 2016; Pekkarinen \& Ulkuniemi, 2008; Tuunanen et al., 2012; Voss \& Hsuan, 2009) - product, process, organisation. By applying modular design at the product (service-offering) level, the service acquires the modularity feature. This feature translates as the standardisation of service-offering elements and service delivery processes and the forethought of their flexible interconnections for increasing the possibilities of customisation during service delivery (Skačkauskienė \& Vestertè, 2019).

Empirical service modularisation cases are relatively rare (de Mattos et al., 2019). Noticeably that most of these cases focus on the rationalisation of service delivery through standardisation. However, the service's flexibility concerning the customer's needs is not achieved. In other words, there are no possibilities for customisation when such a request arises. The essence of modularity implementation is to break down the system into stand-alone modules for flexible reassembly as needed and to create the necessary variability without increasing costs. Thus, most of the practical cases do not achieve the full potential of service modularity. For modular service design to be executed suitably, it is necessary to formulate the conditions for the designers properly. These conditions can be formulated when service modularisation objectives correspond with the provider's organisational objectives, and the expected results are clearly stated.

The paper aims to explore how service modularisation objectives are compatible with organisational objectives. The study examines the premises of service modularity and their outcomes on performance. The paper suggests integrating service modularisation objectives into the Balanced Scorecard based on the antecedents of service modularity. Further, the study presents and classifies the methodological potential for creating indicators sets for achieved results evaluation.

\section{Antecedents of service modularisation}

While modularising services, a service provider addresses the challenge of balancing service customisation, which improves customer satisfaction, increases service demand, and standardisation, which helps streamline processes and reduce costs (Gremyr et al., 2018; Meyer \& DeTore, 1999; Rahikka et al., 2011; Skačkauskienè \& Vestertė, 2020a; Sundbo, 1994; Tuunanen \& Cassab, 2011). If focusing solely on streamlining processes, a provider runs the risk of not hearing customer requirements that determine service satisfaction. Conversely, focusing solely on a customer, who cannot pinpoint what (s)he needs exactly, may unreasonably increase costs in response to service delivery efficiency. According to Skačkauskienè and Vestertè (2020a), if a service provider balances these opposites - service customisation and standardisation - during service modularisation initiative, it is possible to receive the overall benefit - increased service competitiveness. Competitive service ensures profitability and growth.

Service-profit chain model (Heskett et al., 2008) refers to the factors influencing the increase in service profitability. The model claims the existence of an indirect relationship between service profitability and service quality. It presents service quality in two meanings: how customers experience quality (perceived quality) and how a provider recognises quality (internal quality). Anderson et al. (1997) clarify the interpretation and use of the multidimensional concept of quality in the context of services. According to them, a vast concept of quality can be divided into two main categories: 1) quality that meets the needs of customers, and 2) quality that is characterised by the absence of defects. The first quality category in the services' context means that the services comply with customer requirements, and their smooth delivery satisfies customers. The researchers call this quality category as customisation quality. It is created through service customisation actions, the possibility of which is more or less pre-thought by a provider before the service delivery. Customisation is understood as a situation where an individual client receives an individually tailored solution to solve his(er) problem or needs (Sundbo, 2002). The second quality category - the absence of defects - means that service delivery is reliable and guarantees that customers can receive a service without significant deviations from the positive experience regardless of the circumstances. Anderson et al. (1997) propose to consider this quality as standardisation quality. Standardisation means that appropriate conditions are created to replicate an identical product each time (Sundbo, 2002).

Service modularisation achieves the manifestations of both service customisation and standardisation qualities if embodied suitably (Skačkauskienė \& Vestertè, 2020b). Customisation actions during service delivery produce customisation quality. A provider considers the possibility of these actions in advance when designing services on modular principles. Service designers, considering customer participation in service delivery process, decouple services into modules in such a way as to create variants of service offering and delivery that are meaningful to customers and provide specific benefits. They also achieve service standardisation during service design by refining service offering, reducing its vagueness, designing delivery processes that correspond to the service offering elements and standardising the interfaces connecting them. Properly adapted modular design for services must increase customisation quality and standardisation quality. Engineering decisions made during service design must ensure this. 
The increase of overall quality may produce a twofold impact on service profitability. Wirtz and Lovelock (2018) noted that not all efforts to improve service quality convert into increased profitability. Customers do not perceive all quality improvements as essential and are reluctant to pay for them. A provider might comprehend that to standardise and streamline as much as possible is beneficial as these actions reduce the number of defects or errors, minimise costs, and raise service profitability. However, standardisation may not always be acceptable to customers. Of course, customers want the service provision is smooth and without errors, but they might be ready to pay extra for exceptions or customisation actions. Therefore, a provider needs to make those service quality improvements that are likely to affect customer satisfaction significantly. Enhancing customer satisfaction develops customer loyalty, which raises service profitability (Heskett et al., 2008). The empirical facts validate (Wirtz \& Zeithaml, 2018) that providers who orient service delivery in a way that maximises customer satisfaction improve financial performance in the long run.

Thus, by launching service modularisation initiative, a provider seeks to improve service quality through customisation and standardisation activities. During service design, the engineering decisions should pursue to consolidate the effects of service customisation and standardisation qualities so that customer satisfaction would improve simultaneously generating higher revenues, and productivity would increase or remain unchanged (Skačkauskienė \& Vesterté, 2020b). Evaluating the design decisions results requires establishing indicators that incorporate customisation quality and standardisation quality parameters and productivity in advance.

\section{Integrating service modularity premises with organisational performance measurements}

A provider seeks service competitiveness by modularizing services (Skačkauskienė \& Vestertè, 2020a). Whether the competitiveness increases by offering products customers want at a lower cost (lower price) or differentiating products so that customers tend to pay a higher price (Cole \& Kelly, 2020), overall performance results reflect the obtained success.

Modern organisations no longer maintain performance measurement solely on financial indicators and historical data but aim to gain full visibility. Managers review organisational performance in different perspectives simultaneously. According to Cole and Kelly (2020), one of the most commonly used methodologies for a performance review in modern organisations is the Balanced Scorecard. The methodology developed by Kaplan and Norton (1992) enables a comprehensive performance assessment, also considering competitiveness determinants. Notably, organisations also use other performance evaluation methodologies (Kerzner, 2017), such as Total Quality Management, Six Sigma, Hoshin Kanri X matrix, and similar. In practice, organisations often integrate performance measurement methodologies to obtain the performance management system most suited for organisation needs.

The Balanced Scorecard is relatively simple and easily compatible with other performance-enhancing methodologies. The essence of its implementation is developing a measurement and communication tool, linking it with organisational strategy. Implementing the Balanced Scorecard can be considered as a foundation for preparing an organisation for improvement. Therefore suggested, a provider follows the principles of this methodology initially when planning service modularisation for achieving compatibility with organisational objectives, and, if necessary, later integrating the formulated objectives into the used performance evaluation system.

The Balanced Scorecard development begins with the organisation's leaders refining its vision, mission, and strategy. After introducing the organisational strategic goals, producing the so-called Strategic Linkage Model or Strategy Map follows. The Strategy Map encompasses objectives broken down by perspectives, activities, and results. The first version of the Balanced Scorecard (Kaplan \& Norton, 1996) proposed four main perspectives through which organisations should evaluate their performance: 1) finance, 2) customers, 3) internal processes, 4) learning and growth. In practice, organisations using balanced scorecards additionally include other perspectives (Cole \& Kelly, 2020; Kerzner, 2017; Parmenter, 2020) like social responsibility, innovation, employees, etc. In the Strategy Map, the cause-and-effect relationships connect the established objectives. Afterwards, the selection of appropriate indicators for each objective and assignment of the responsible persons occurs.

Considering the antecedents of service modularisation and following the logic of service-profit chain model (Heskett et al., 2008), it is possible to specify the organisational objetives related to service modularisation and highlight the cause-and-effect relationships between them (Figure 1).

Relying on the four perspectives initially proposed by Kaplan and Norton (1992), but in the context of a service organisation, the captioning of the third (internal processes) and fourth perspectives (learning and growth) needs clarification. The result created by a service organisation - a service - is a process that includes both internal and external processes, so the appropriate captioning of the third perspective would be product/processes. The role of employees in service delivery is critical as their qualifications, capabilities, and motivation largely determine the service quality. So, it is proposed to adjust the captioning of the fourth section to employees. 


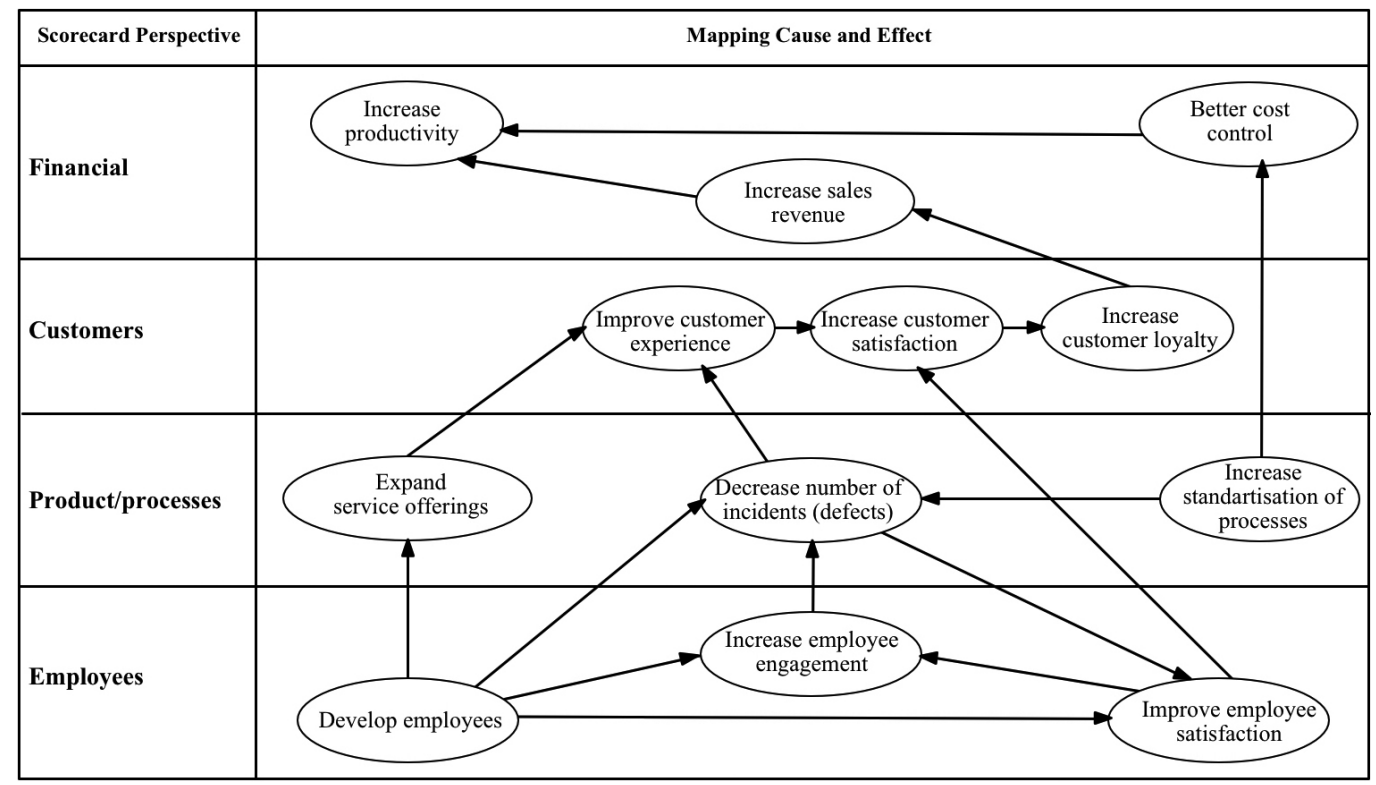

Figure 1. Integrating service modularity objectives into a balanced scorecard (source: created by authors)

\section{Measuring service modularity outcome}

After structuring the objectives of service modularisation, it is possible to settle indicators reflecting the achieved outcome. The performance indicators for financial, customer, product, employee perspectives are presented taking into account the recommendations proposed by Franceschini et al. (2007), Kerzner (2017), Marr (2012), Parmenter (2020).

\subsection{Financial perspective}

The data for the financial perspective's performance indicators (Table 1) are collected from the organisation's financial accounts. Productivity growth is measured by the ratio of operating expenses to income. Changes in this indicator over time express the organisation's ability to increase revenue without increasing costs proportionately. Sales revenue growth is measured by recording the rate of revenue growth - an organisation's ability to increase its sales revenue over a period of time. As an organisation expands, operating expenses reductions are unlikely. However, opportunities and ways to reduce them must be sought continuously: negotiating better conditions with suppliers, implementing process automation technologies, and similar. A closer look at the absolute values of the individual operating expenses items allows for better supervision. It is proposed to record the dynamics of operating expenses required to obtain an operating result (provision of services) at certain intervals and to control the established permissible growth limits. The operating expenses structure varies from area to area. Usually, it includes payroll, costs of materials, outsourcing and insourcing costs, office maintenance, accounting, marketing, research and development (R\&D), transport/travel costs, licenses, property, insurance, etc.

Table 1. Formation of indicators for achieving objectives from the financial perspective (source: created by authors)

\begin{tabular}{|c|c|c|}
\hline Objective & Indicators & Measure, desired direction \\
\hline Increase productivity & $\begin{array}{l}\text { Operating expense ratio (OER): } \\
O E R=\frac{O P E X_{t}}{P_{t}} \times 100 \\
O P E X_{t}-\text { operating expenses (OPEX) in period } t \\
P_{t}-\text { net sales in period } t\end{array}$ & $\%, \downarrow$ \\
\hline Increase sales revenue & $\begin{array}{l}\text { Revenue growth rate (RGR): } \\
R G R=\frac{\left(P_{1}-P_{2}\right)}{P_{2}} \times 100 \\
P_{1}-\text { current period revenue; } \\
P_{2}-\text { prior period revenue }\end{array}$ & $\%, \uparrow$ \\
\hline Better cost control & $\begin{array}{l}\text { Operating expenses (OPEX): } \\
\text { OPEX }=\sum_{i=1}^{n} S_{i t} \\
S_{i t}-\text { cost for position } i \text { in period } t\end{array}$ & Currency (EUR), increase limits are set \\
\hline
\end{tabular}




\subsection{Customer perspective}

The values of the proposed indicators of achieving the customer perspective's objectives (Table 2) are calculated using qualitative research methods. Therefore, the collection of the required data may take longer and require additional costs.

Table 2. Formation of indicators for achieving objectives from the customer perspective (source: created by authors)

\begin{tabular}{|c|c|c|}
\hline Objective & Indicators & Measure, desired direction \\
\hline \multirow{2}{*}{ Increase customer loyalty } & $\begin{array}{l}\text { Net promoter score (NPS): } \\
N P S=\frac{R-N}{k} \times 100 \\
R-\text { number of customers who rated with } 9-10 \text { score (promoters); } \\
N-\text { number of customers who rated with } 0-6 \text { score (detractors); } \\
k-\text { number of respondents }\end{array}$ & $\%, \uparrow$ \\
\hline & $\begin{array}{l}\text { Customer retention rate (CRR): } \\
C R R=\frac{k_{2}}{k_{1}} \times 100 \\
k_{1}-\text { number of customers at the beginning of the period; } \\
k_{2}-\text { number of customers at the end of the period }\end{array}$ & $\%, \uparrow$ \\
\hline \multirow{2}{*}{$\begin{array}{l}\text { Increase customer } \\
\text { satisfaction }\end{array}$} & $\begin{array}{l}\text { Customer satisfaction index (CSI): } \\
\qquad S I=\frac{\sum_{i=1}^{n} w_{i} p_{i}}{n} \\
n-\text { number of selected criteria assessing customer satisfaction; } \\
p \text { - criteria } i \text { assessing customer satisfaction; } \\
w \text { - weight of customer satisfaction criteria } i\end{array}$ & Ratio, $\uparrow$ \\
\hline & $\begin{array}{l}\text { Customer engagement ratio (CER): } \\
C E R=\frac{e_{1}}{e_{2}} \\
e_{1}-\text { number of fully engaged customers } \\
e_{2}-\text { number of actively disengaged customers }\end{array}$ & Ratio, $\uparrow$ \\
\hline $\begin{array}{l}\text { Improve customer } \\
\text { experience }\end{array}$ & $\begin{array}{l}\text { Customer complains index (CCI): } \\
C C I=\frac{\sum_{i=1}^{n} w_{i} c_{i}}{n} \\
n \text { - number of selected criteria for evaluating customer complaints; } \\
c \text { - criteria } i \text { for evaluating customer complaints; } \\
w \text { - weight of criteria } i \text { evaluating customer complaints }\end{array}$ & Ratio, $\downarrow$ \\
\hline
\end{tabular}

It is practicable to measure the increase in customer loyalty by two indicators - Net Promoter Score (NPS) and Customer Retention Rate (CRR). NPS evaluates an organization's performance from a customer perspective and allows assumptions about customer loyalty. NPS calculation data is collected during surveys by asking a single question - how likely is it that you would recommend our company/product/service to a friend or colleague? Respondents rate answers from 0 (not likely to recommend) to 10 (extremely likely to recommend) scores. Depending on the answers, customers are divided into groups:

- promoters who rated with a score of 9-10, will continue to buy and recommend to others;

- passive who rated with a score of 7-8, satisfied customers, but can easily switch to competitors;

- detractors who rated with a score 0-6, dissatisfied customers who give negative feedback.

After summing the received answers in each group, the NPS is found according to the given formula (Table 2, Formula 1).

The Customer Retention Rate (Table 2, Formula 2) describes customer loyalty based on actual customer actions: how many existing customers remain or repurchase. As a provider may not want to keep all customers loyal (unprofitable, expensive to service, low life cycle value, etc.), certain decrease margins should be allowed for this indicator.

Customer Satisfaction Index (CSI) and Customer Engagement Ratio (CER) serve for measuring customer satisfaction. CSI (Table 2, Formula 3) shows the gap between perceived service and expectations. Customer surveys collect both qualitative and quantitative data describing customer satisfaction. The criteria for assessing customer satisfaction are selected independently by organisations, although there are commonly used criteria by area. It is practicable to assign weights to selected criteria. CER (Table 2, Formula 4) measures customer relationship strength with an organisation. Noticeable that customers may be satisfied, but still choose competitors. There are various practices for 
obtaining the value of this indicator. One of the most popular is the Gallup method. Customers answers 11 questions of emotional nature and rate on a Likert scale ( 1 - strongly disagree; 5 - strongly agree). Depending on the answers, customers fall into groups:

- fully engaged customers who are emotionally attached and rationally loyal, the most valuable customers of the organisation;

- engaged customers who begin to feel emotional engagement;

- disengaged customers who are emotionally and rationally neutral;

- actively disengaged customers who are emotionally detached and actively opposing.

The ratio between fully engaged customers and actively disengaged customers shows how many fully engaged customers exist per one actively disengaged customer. For example, a ratio value of 4.9 means that 1 actively disengaged customer has 4.9 fully engaged customers.

According to Jain et al. (2017), customer experience evaluation indicators still require research. The literature reviewed by the authors provides suggestions for evaluating the customer experience using the following scales and indices, which are quite complex and expensive to use and are therefore not widely used in practice:

- Experiential Value Scale;

- Brand Experience Scale;

- Customer Experience Index;

- Service Experience Quality Scale;

- Retail Customer Experience Scale.

Customer Complains Index (CCI) can indirectly assess the customer experience. This indicator makes it possible to judge customer dissatisfaction and aids to identify the necessary actions to improve the customer experience. Most dissatisfied customers do not make complaints. They simply stop buying. However, the majority of those who complain and whose complaints are resolved quickly remain satisfied and loyal. It is proposed to compile an index (Table 2, Formula 5) consisting of various criteria that are most appropriate for organisational specifics: number of complaints per number of services provided, average complaint resolution time, complaint resolution costs, number of positively resolved (customer remains satisfied) complaints, types of complaints (delays, faults, rude service, etc.) frequency, and similar.

\subsection{Product/process perspective}

The choice of product/process perspective indicators (Table 3) depends on the provided services' specifics. A popular practical way to determine if a service meets the market's needs is to take the Sean Ellis test and calculate the level of marketability of the product (Table 3, Formula 1). This indicator allows assessing whether the offered service solves customer problems-needs. A representative sample of customers answers a question - how would you feel if you could no longer use our product [service]? The possible reply choices are very disappointed, somewhat disappointed, not disappointed (it really is not that useful). If more than $40 \%$ of respondents choose the answer as very disappointed, then the product fit level is considered sustainable.

Defects per Opportunity (DPO) (Table 3, Formula 2) and Defects per Unit (DPU) (Table 3, Formula 3) allows assessing the smooth functioning of processes. For using these indicators, it is necessary to differentiate between an opportunity and a unit in the context of the services provided. A unit is what a customer needs as a whole. A unit can possess various features. For example, a call to a contact centre can be considered a unit. Its features would be fast response time, quick referral to the right person, capability to solve an addressed problem, positive emotional contact, and similar.

The indicators utilised to assess the standardisation of the service provider's processes depend primarily on the organisation's specifics and the area of services provided, determining the standards used. Deviations from the established standards can be assessed using indicators that assess the characteristics of delivery time required, resources used, waste generated, etc. (Table 3, Row 3).

\subsection{Employee perspective}

The data needed to calculate the proposed indicators for employee perspective (Table 4) are mainly obtained with qualitative methods. Whether employees qualification is improving can be assessed indirectly by using the return on investment of training. This indicator helps to orientate whether the training of employees is effective. Based on the Philips ROI model, qualitative and quantitative data are collected and processed in 5 steps: 1) feedback from participants and planned actions after the training; 2) assessment of what participants have learned in the training program; 3) assessment of how participants apply knowledge in their work - changes in actions, use of new methods, etc.; 4) evaluation and expression of the impact of training on work results (quality, time spent, costs, customer satisfaction, etc.) in monetary units; 5) calculation of return to learning according to the relevant formula (Table 4, Formula 1). 
Employee Engagement Ratio (EER) assesses employees' readiness to achieve organisational goals and objectives (Table 4, formula 2). A popular way to collect data for calculating this ratio is Gallup's 12-question questionnaire, revealing the key characteristics of engagement. According to the collected answers, employees fall into three groups: 1) engaged; 2) not engaged; 3) actively disengaged.

Employee Satisfaction Index (ESI) evaluates whether employees are satisfied with their work or their needs are taken care of (Table 4, formula 3). Data are collected by anonymously interviewing employees. The questions correspond to organisational specifics, usually covering the following areas: 1) leadership; 2) communication; 3) relationships with line managers; 4) opportunities for improvement; 5) work culture; 6) working conditions; 7) financial and non-financial rewards. Respondents use the Likert scale for answering ( 1 - strongly disagree; 5 - strongly agree).

Completing an overview of possible indicators for accessing the outcome of service modularisation leads to the conclusion that the methodological potential is sufficient for this task. Although the data needed to calculate most indicators are collected using qualitative methods, respecting compliance with qualitative methods requirements can

Table 3. Formation of indicators for achieving objectives from the product/process perspective (source: created by authors)

\begin{tabular}{|c|c|c|}
\hline Objective & Indicators & Measure, desired direction \\
\hline $\begin{array}{l}\text { Expand service } \\
\text { offerings }\end{array}$ & $\begin{array}{l}\text { Product-market fit level (PMF): } \\
P M F=\frac{D}{k} \times 100 \\
D-\text { number of customers who choose very disappointed; } \\
k-\text { number of respondents }\end{array}$ & $\%,>40 \%$ and $\uparrow$ \\
\hline $\begin{array}{l}\text { Decrease number of } \\
\text { incidents (defects) }\end{array}$ & $\begin{array}{l}\text { Defects per opportunity (DPO): } \\
D P O=\frac{d}{o} \\
d \text { - number of defected features; } \\
o \text { - total number of features } \\
\text { Defects per unit (DPU): } \\
D P U=\frac{d}{u} \\
d-\text { defected units in a sample; } \\
u-\text { total number of units in a sample }\end{array}$ & Ratio, $\downarrow$ \\
\hline $\begin{array}{l}\text { Increase } \\
\text { standardisation of } \\
\text { processes }\end{array}$ & $\begin{array}{l}\text { Possible indicators: } \\
\text { - Process waste level; } \\
\text { - Order fulfilment cycle time (OFCT); } \\
\text { - Delivery in full, on-time rate (DIFOT); } \\
\text { - First pass yield (FPY); } \\
\text { - Schedule variance (SV); } \\
\text { - Cost variance (CV); } \\
\text { - etc. }\end{array}$ & Depends on particular indicator \\
\hline
\end{tabular}

Table 4. Formation of indicators for achieving objectives from the employee perspective (source: created by authors)

\begin{tabular}{|c|c|c|}
\hline Objective & Indicators & Measure, desired direction \\
\hline Develop employees & $\begin{array}{l}\text { Training Return on Investment (TROI): } \\
\text { TROI }=\frac{B-C}{C} \times 100 \\
B \text { - training program benefits expressed in monetary units (EUR); } \\
C \text { - training program costs }\end{array}$ & $\%, \uparrow$ \\
\hline $\begin{array}{l}\text { Increase employee } \\
\text { engagement }\end{array}$ & $\begin{array}{l}\text { Employee Engagement Ratio (EER): } \\
E E R=\frac{d_{1}}{d_{2}} \\
d_{1}-\text { fully engaged employees }(\%) ; \\
e_{2}-\text { actively disengaged employees }(\%)\end{array}$ & Ratio, $\uparrow$ \\
\hline $\begin{array}{l}\text { Improve employee } \\
\text { satisfaction }\end{array}$ & $\begin{array}{l}\text { Employee Satisfaction Index (ESI): } \\
E S I=\frac{\sum_{i=1}^{n} \sum_{j=1}^{m} b_{i j}}{n \times m} \\
b_{i j} \text { - score of respondent } j \text { to a question } i \\
n-\text { number of questions; } \\
m \text { - number of respondents }\end{array}$ & Ratio, $\uparrow$ \\
\hline
\end{tabular}


provide reliable values for the indicators. The most problematic is to choose the tools to assess the improvement of customer experience and employee development. However, there is also a possible solution by employing indirect assessments. Certainly, a provider must consider the type and specificity of services and include the necessary additional indicators when integrating the assessment of service modularisation outcome into a balanced scorecard.

\section{Conclusions}

This paper set out to develop a framework to translate the service modularity antecedents into organisational objectives. The form identified relates to using the Balanced Scorecard methodology steps by preparing the Strategic Linkage Model and selecting the appropriate performance indicators for measuring results. This led to the structuring of service modularisation objectives and their possible integration into the organisational goal system.

The proposed structuring of organisational objectives related to service modularisation clarifies what a provider aims when undertaking a service modularisation initiative. The Balanced Scorecard methodology allows integrating the main antecedents of service modularisation into organisational objectives. By monitoring and evaluating indicators included into the Balanced Scorecard, a provider is enabled to seek the balance of customisation and standardisation qualities (customer, product/process, employee perspectives) and an increase of productivity (financial perspective). The four perspectives of the Balanced Scorecard provide a reliable picture of the state of service competitiveness. However, to have a complete assessment of service competitiveness, a provider should compare the information from a balanced scorecard to other market participants' performance and positions.

The existing methodological potential for forming a set of indicators reflecting the achievement of organisational goals related to modularisation is sufficient. As the data needed to calculate the indicators exists in one form or another in service organisations, a provider should review its organisational objectives and performance measurements and, if necessary, modify and add elements related to the service modularisation initiative. A provider can elaborate conditions and requirements for modular design after service modularisation and organisational objectives integration and selection of appropriate indicators. Knowing clearly what a provider aspires to achieve can lead to more rational decisions on service modularity planning. Further, this study's results will serve as a basis for developing a decision support tool for service modularity planning.

\section{References}

Anderson, E. W., Fornell, C., \& Rust, R. T. (1997). Customer satisfaction, productivity, and profitability: Differences between goods and services. Marketing Science, 16(2), 129-145. https://doi.org/10.1287/mksc.16.2.129

Baldwin, C. Y., \& Clark, K. B. (2000). Design rules: The power of modularity (4 ed., Vol. 1). The MIT Press. https://doi.org/10.7551/mitpress/2366.001.0001

Bask, A., Lipponen, M., Rajahonka, M., \& Tinnilä, M. (2011). Framework for modularity and customization: Service perspective. Journal of Business \& Industrial Marketing, 26(5), 306-319. https://doi.org/10.1108/08858621111144370

Cole, G. A., \& Kelly, P. (2020). Management theory and practice (9 ed.). Cengage Learning EMEA.

de Mattos, C. S., Fettermann, D. C., \& Cauchick-Miguel, P. A. (2019). Service modularity: Literature overview of concepts, effects, enablers, and methods. The Service Industries Journal. https://doi.org/10.1080/02642069.2019.1572117

Franceschini, F., Galetto, M., \& Maisano, D. (2007). Management by measurement: Designing key indicators and performance measurement systems. Springer.

Gremyr, I., Valtakoski, A., \& Witell, L. (2018). Two routes of service modularization: Advancing standardization and customization. Journal of Services Marketing, 33(1), 73-87. https://doi.org/10.1108/JSM-10-2018-0285

Heskett, J. L., Jones, T. O., Loveman, G. W., Sasser, E., \& Schlesinger, L. A. (2008). Putting the service-profit chain to work. Harvard Business Review, 2008(July-August). https://hbr.org/2008/07/putting-the-service-profit-chain-to-work

Jain, R., Aagja, J., \& Bagdare, S. (2017). Customer experience - a review and research agenda. Journal of Service Theory and Practice, 27(3), 642-662. https://doi.org/10.1108/JSTP-03-2015-0064

Kaplan, R. S., \& Norton, D. P. (1992). The balanced scorecard: Measures that drive performance. Harvard Business Review, 1992(January-February), 71-79. https://hbr.org/1992/01/the-balanced-scorecard-measures-that-drive-performance-2

Kaplan, R. S., \& Norton, D. P. (1996). The balanced scorecard: Translating strategy into action. Harvard Business School Press.

Kerzner, H. (2017). Project management metrics, KPIs, and dashboards: A guide to measuring and monitoring project performance. Wiley. https://doi.org/10.1002/9781119427599

Løkkegaard, M., Mortensen, N. H., \& McAloone, T. C. (2016). Towards a framework for modular service design synthesis. Research in Engineering Design, 27(3), 237-249. https://doi.org/10.1007/s00163-016-0215-6

Marr, B. (2012). Key performance indicators: The 75 measures every manager nedds to know. Pearson.

Meyer, M. H., \& DeTore, A. (1999). Product development for services. The Academy of Management Executive, 13(3), 64-76. https://doi.org/10.5465/ame.1999.2210315

Parmenter, D. (2020). Key performance indicators: Developing, implementing, and using winning KPIs. John Wiley \& Sons, Inc. https://doi.org/10.1002/9781119620785 
Pekkarinen, S., \& Ulkuniemi, P. (2008). Modularity in developing business services by platform approach. The International Journal of Logistics Management, 19(1), 84-103. https://doi.org/10.1108/09574090810872613

Porter, M. E. (1996). What is strategy? Harvard Business Review, 1996(November-December), 61-78. https://hbr.org/1996/11/what-is-strategy

Rahikka, E., Ulkuniemi, P., \& Pekkarinen, S. (2011). Developing the value perception of the business customer through service modularity. Journal of Business \& Industrial Marketing, 26(5), 357-367. https://doi.org/10.1108/08858621111144415

Skačkauskienè, I., \& Vestertè, J. (2019). Modulinio projektavimo taikymo paslaugoms problematika [Problematic of service modularisation]. Mokslas - Lietuvos ateitis / Science - Future of Lithuania, 11, 1-9. https://doi.org/10.3846/mla.2019.9195

Skačkauskienė, I., \& Vestertè, J. (2020a). Peculiarities of planning for service modularity. International Journal of Learning and Change. https://doi.org/10.1504/IJLC.2020.10028495

Skačkauskienè, I., \& Vestertè, J. (2020b). Tasks for service modularization planning. Business: Theory and Practice, 21(2), 813-819. https://doi.org/10.3846/btp.2020.12776

Sundbo, J. (1994). Modulization of service production and a thesis of convergence between service and manufacturing organizations. Scandinavian Journal of Management, 10(3), 245-266. https://doi.org/10.1016/0956-5221(94)90002-7

Sundbo, J. (2002). The service economy: Standardisation or customisation? Service Industries Journal, 22(4), 93-116. https://doi.org/10.1080/714005099

Tuunanen, T., Bask, A., \& Merisalo-Rantanen, H. (2012). Typology for modular service design: Review of literature. International Journal of Service Science, Management, Engineering, and Technology, 3(3), 99-112. https://doi.org/10.4018/jssmet.2012070107

Tuunanen, T., \& Cassab, H. (2011). Service process modularization: Reuse versus variation in service extensions. Journal of Service Research, 14(3), 340-354. https://doi.org/10.1177/1094670511413912

Voss, C. A., \& Hsuan, J. (2009). Service architecture and modularity. Decision Sciences, 40(3), 541-569. https://doi.org/10.1111/j.1540-5915.2009.00241.x

Wirtz, J., \& Lovelock, C. (2018). Essentials of services marketing (3 ed.). Pearson Education.

Wirtz, J., \& Zeithaml, V. (2018). Cost-effective service excellence. Journal of the Academy of Marketing Science, 46(1), 59-80. https://doi.org/10.1007/s11747-017-0560-7 